\title{
PHYTOPLANKTON FLORA OF TANGUAR HAOR ECOSYSTEM IN BANGLADESH: CYANOPHYTA, PYRRHOPHYTA, CHRYSOPHYTA AND EUGLENOPHYTA
}

\author{
Bhuiyan, M. A. H., S. A. M. S. Islam, A. Kowser, M. R. Islam, S. A. Kakoly, K. Asaduzzaman ${ }^{1}$ and M. \\ Khondker \\ Department of Botany, University of Dhaka, Dhaka-1000, Bangladesh; ${ }^{1}$ Bangladesh Atomic Energy \\ Commission, Savar, Dhaka -1349, Bangladesh
}

\begin{abstract}
The present paper is dealt with the composition and density of the population of pelagic phytoplankton collected from two studied stations, namely Watch Tower and Rauar Station of Tanguar Haor in Sunamganj District. Plankton belonging to the divisions Cyanophyta, Pyrrhophyta, Chrysophyta and Euglenophyta were studied from bimonthly collected samples during 2017 and 2018. Division Cyanophyta was represented by the occurrence of 17 species followed by Chrysophyta (16 spp.), Euglenophyta (4 spp.) and Phyrrhophyta (2 spp.). The most dominant plankton taxon was Dinobryon sertularia Ehrenberg whose density was $374 \times 10^{3}$ ind $/ 1$ and $137.5 \times 10^{3} \mathrm{ind} / 1$ at Watch Tower and Rauar Station, respectively. Euglenoid population was relatively poorer compared to the other groups of phytoplankton. Abundant population of D. sertularia designates the Tanguar Haor ecosystem as moderate in terms of productivity. A total of 39 species recorded from three algal divisions, namely Cyanophyta, Pyrrhophyta, Chrysophyta and Euglenophyta. Tanguar Haor ecosystem was included with mean phytoplankton population of Cyanophyta, Pyrrhophyta, Chrysophyta and Euglenophyta.
\end{abstract}

Keywords: Phytoplankton; Tanguar haor; Cyanophyta; Phyrrhophyta; Chrysophyta; Euglenophyta.

\section{INTRODUCTION}

Phytoplankton flora is a dominant photoautotrophic community in the pelagic region of almost all lake ecosystems (Prescott 1982, Reynolds 1984). Their quality (taxonomic diversity) and quantity (population density) play a significant role in the overall biological production of any aquatic ecosystem as well as they could be utilized to characterize the trophicity of water. Moreover, the formation of water bloom, the main causal element for fish mortality in water bodies, is also pertinent to the floristic composition of phytoplankton and dissolved nutrients of water (Prescott 1982, Khondker et al. 1990). In Bangladesh, a significant number of floristic works on phytoplankton have been carried out targeting their composition in ponds, rivers and artificial lakes (Islam et al. 1991, Islam et al. 2001, Bhuiyan and Khondker 2018).

The haor ecosystems of Bangladesh have been supporting a significant number of plants starting from micro-algae to large wetland trees. Microalgae, the major constituent of phytoplankton serve as the basis of primary production for higher consumers. The composition and quantity of phytoplankton on the other hand do depend upon a number of physicochemical factors. Islam and Paul (1978) studied the floristic composition of both phytoplankton and higher aquatics of the Haor Hakaluki in greater Sylhet Division. Since then there has been no other information on the floristic composition of phytoplankton from the haor ecosystems of Bangladesh. Recently, Bhuiyan et al. $(2018,2019)$ studied the ecosystem of Tanguar Haor of Sunamganj District in respect to the water quality factors and their interrelationships with the phytoplankton biomass as chlorophyll $a$ and cell density. From the trophic standpoint, Tanguar Haor has been characterized as mesotrophic (Bhuiyan et al. 2019). Although, information on wetland trees and fishes are available for Tanguar Haor, there is no information on the qualitative aspects of phytoplankton flora of the Haor. The present investigation has therefore been aimed to present the qualitative aspects of phytoplankton diversity of the Tanguar Haor. 


\section{MATERIAL AND METHODS}

Samples for the present investigation were collected in between the years 2017 and 2018 from two distinct sampling stations of Tanguar Haor, namelyWatch Tower and Rauar Stations (Bhuiyan et al. $2018,2019)$. On each occasion and at each sampling station, one hundred liter of pelagic water of the Haor was passed through a plankton net (mesh width $25 \mu \mathrm{m}$ ) and the concentrate accumulated in the bucket of the net was transferred to a glass vial. The sample was fixed with $4 \%$ commercial formalin for further laboratory analysis. Parallel to this collection of phytoplankton samples, plankton concentrates were also obtained via sedimentation technique by Lugol's Iodine (Wetzel and Likens 2000).

From both the above mentioned collected samples, low concentration glycerin mount of a drop of plankton concentrate was studied under a phase contrast microscope (Olympus, Japan). The magnified images (400x) of plankton were taken and their cell dimension and other measurements (length of flagella and/or processes attached to the cells, number of spines and/or striae, etc.) were carried out. The planktons were identified by using Encyclopedia (Flora and Fauna) of Bangladesh (Ahmed et al. 2009), Desikachary (1959), Islam and Khundker (2003), Ling and Tyler (2000), Prescott (1982), Starmach (1982), Huber-Pestalozzi (1968), Hustedt (1930) and Dillard (2000).

The dominant taxa present in the phytoplankton flora of Tanguar Haor ecosystem was also evaluated via counting the population of dominant species. The counting was done by using the Helber Counting Chamber under a Nikon student microscope with a magnification of 400x. The data were transferred to individuals per liter and presented in tabular form (Table 1). Species with small population size were not taken under consideration for counting. These were recorded as present in the community only, since the individual number was too poor to be counted.

\section{RESULTS AND DISCUSSION}

The structure of the planktonic flora of Tanguar Haor has been tabulated in the table to have a look at a glance. Table 1 contains detail structure of the quantitative and qualitative analysis of the planktonic population of the experimental results. Figs. 1-3 show detail photographic structure of the examined phytoplankton found in the experimental station of the Tanguar Haor ecosystem. So far analyses were done orderwise (Table 1) from the examined samples of phytoplankton. It is revealed that the Order Bacillariales was represented by highest number of species (6) followed by Euglenales (4 species). orders like Centrales, Ochromonadales and Peridiniales each with two species were identified and recorded. Nostocales and Chroococcales were represented by two species in each (Table 1). In case of algal Division, the Cyanophyta was with 4 species, Phyrrhophyta with 2 species, Chrysophyta with 10 species and Euglenophyta with 4 species identified and recorded. Members of blue-green (Cyanophyta), dinoflagellates (Pyrrhophyta), golden brown (Chrysophyta) and euglenoid (Euglenophyta) phytoplanktons have been presented (Table 1).

Division Cyanophyta has been represented by four species whose mean density ranged from 4.0$117.5 \mathrm{ind} / \mathrm{l}$. The highest density was shown by Microcystis marginata $\left(117.5 \times 10^{3} \mathrm{ind} / \mathrm{l}\right)$. Chroococcus disperses showed a value of $4.0 \times 10^{3}$ ind/l. Of the dominant population from the cyanophytes, Rauar Station of Tanguar Haor was poorly represented (Table 1). Some other species of cyanophytes were obtained from the Haor, these are: Arthrospira platensis, Gloeotrichia echinulata, Rivularia globiceps, Raphidiopsis mediterranea, Oscillatoria formosa, O. tenuis, O. peronata, O. chalybea, Pseudanabaena schmidlei, Anabaena constricta, Anabaena affinis, A. californica and Anabaenopsis racibowrski. So, a total of 17 species from the blue-green algae was recorded from the Tanguar Haor ecosystem. Of which 13 species were recorded as just present in the system. From the freshwater dinoflagellates two species were recorded. Their cell density varied from $1.5-145 \times 10^{3}$ ind/l. From the dinoflagellates Ceratium furca was dominant in both the studied stations (Table 1). Among the chrysophytes two species were 
recorded, namely Dinobryon sertularia and Mallomonas akrokomos. Of which, D. sertularia was dominant in both the studied stations. Its cell density was recorded as $374 \times 10^{3} \mathrm{ind} / 1$ and $137.5 \times 10^{3}$ ind/l for Watch Tower and Rauar Station, respectively.

Table 1. Qualitative and quantitative accounts of phytoplankton of Cynaophyta, Pyrrhophyta, Chrysophyta and Euglenophyta collected from two study stations of Tanguar Haor (counting data represents mean density).

\begin{tabular}{|c|c|c|c|c|c|c|}
\hline \multirow[t]{2}{*}{ Division } & \multirow[t]{2}{*}{ Order } & \multirow[t]{2}{*}{ Species } & \multicolumn{2}{|c|}{ Stations* } & \multirow[t]{2}{*}{ Fig. } & \multirow[t]{2}{*}{ References } \\
\hline & & & Watch Tower & Rauar & & \\
\hline \multirow{4}{*}{ 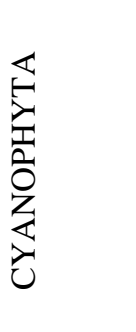 } & \multirow[t]{2}{*}{ Chroococcales } & $\begin{array}{l}\text { Microcystis marginata } \\
\text { (Menegh.) Kuetz. }\end{array}$ & 117.5 & 78 & Figs. 1s-v & $\begin{array}{l}\text { Desikachary } \\
\text { (1959) }\end{array}$ \\
\hline & & $\begin{array}{l}\text { Chroococcus dispersus } \\
\text { (Keissel.) Lemm. }\end{array}$ & 4.0 & - & Fig.1r & $\begin{array}{l}\text { Khondker et al. } \\
\text { (2006) }\end{array}$ \\
\hline & \multirow[t]{2}{*}{ Nostocales } & $\begin{array}{l}\text { Oscillatoria chalybea } \\
\text { (Mertens) Gomont }\end{array}$ & 15.0 & 19 & Fig. $2 \mathrm{~g}$ & $\begin{array}{l}\text { Islam and Zaman } \\
\text { (1975) }\end{array}$ \\
\hline & & $\begin{array}{l}\text { Arthrospira platensis } \\
\text { (Nordst.) Gomont }\end{array}$ & 26.5 & 15.5 & Fig. $1 \mathrm{w}$ & $\begin{array}{l}\text { Desikachary } \\
(1959)\end{array}$ \\
\hline \multirow{2}{*}{ 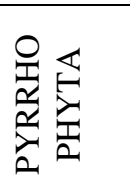 } & \multirow[t]{2}{*}{ Peridiniales } & $\begin{array}{l}\text { Ceratium furca (Ehrenberg) } \\
\text { Claprède } \text { et Lachmann }\end{array}$ & 145 & 106.5 & Figs. 1o-q & $\begin{array}{l}\text { Islam and Aziz } \\
\text { (1975) }\end{array}$ \\
\hline & & Peridinium $\mathrm{sp}$. & - & 1.5 & - & $\begin{array}{l}\text { Khondker } \text { et al. } \\
\text { (2009) }\end{array}$ \\
\hline \multirow{10}{*}{ 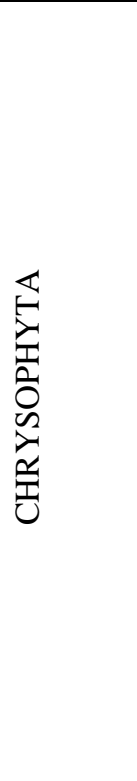 } & \multirow[t]{2}{*}{ Ochromonadales } & $\begin{array}{l}\text { Dinobryon sertularia } \\
\text { Ehrenberg }\end{array}$ & 374 & 137.5 & Figs. 1g-h & $\begin{array}{l}\text { Islam and } \\
\text { Irfanullah } \\
(2005)\end{array}$ \\
\hline & & $\begin{array}{l}\text { Mallomonas akrokomos } \\
\text { Ruttner mscr. in Pascher }\end{array}$ & 5 & - & Figs. 1i-j & $\begin{array}{l}\text { Khondker et al. } \\
\text { (2007) }\end{array}$ \\
\hline & \multirow[t]{2}{*}{ Centrales } & $\begin{array}{l}\text { Coscinodiscus lacustris } \\
\text { Grun. }\end{array}$ & 7.5 & - & Fig. 2a & $\begin{array}{l}\text { Islam and } \\
\text { Haroon (1975) }\end{array}$ \\
\hline & & $\begin{array}{l}\text { Melosira granulata } \\
\text { (Ehrenberg) Ralfs in } \\
\text { Pritchard }\end{array}$ & 291 & 34.5 & Figs.1b-c & $\begin{array}{l}\text { Islam and } \\
\text { Haroon (1975) }\end{array}$ \\
\hline & \multirow[t]{6}{*}{ Bacillariales } & Fragilaria virescens Ralfs & 32.5 & - & Fig. $2 \mathrm{~s}$ & Germain (1981) \\
\hline & & Denticula tenuis Kütz. & 94 & 61 & Figs. $2 \mathrm{e}-\mathrm{g}$ & Hustedt (1930) \\
\hline & & Eunotia monodon Ehr. & 8 & 9.5 & Figs. 2p-r & $\begin{array}{l}\text { Islam and } \\
\text { Haroon (1975) }\end{array}$ \\
\hline & & $\begin{array}{l}\text { Cymbella cistula (Hemp and } \\
\text { Ehr. ) Kirchner }\end{array}$ & - & 9.5 & Figs. 2h-i & $\begin{array}{l}\text { Islam and } \\
\text { Haroon (1975) }\end{array}$ \\
\hline & & $\begin{array}{l}\text { Gomphonema lanceolatum } \\
\text { Ehrenberg }\end{array}$ & - & 44 & Fig. $2 \mathrm{~m}$ & $\begin{array}{l}\text { Islam and } \\
\text { Haroon (1975) }\end{array}$ \\
\hline & & G.gracile Ehrenberg & 1.5 & 3 & Fig. 2n-o & Germain (1981) \\
\hline \multirow{4}{*}{ 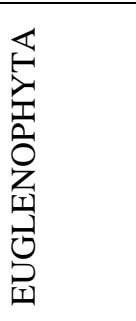 } & \multirow[t]{4}{*}{ Euglenales } & $\begin{array}{l}\text { Euglena charkowiensis } \\
\text { Swirenko }\end{array}$ & 1.5 & - & Fig. 1i & Khondker (2009) \\
\hline & & $\begin{array}{l}\text { Phacus longicauda } \\
\text { (Ehrenberg) Dujardin }\end{array}$ & - & 4.5 & Fig. $1 \mathrm{k}$ & $\begin{array}{l}\text { Islam et al. } \\
\text { (1991) }\end{array}$ \\
\hline & & $\begin{array}{l}\text { Trachelomonas } \\
\text { volvocinopsis Swir. }\end{array}$ & 1.5 & - & Fig. 1n & $\begin{array}{l}\text { Islam and } \\
\text { Irfanullah (2005) }\end{array}$ \\
\hline & & T. racibowrski Wolosz. & 4 & - & Fig. $1 \mathrm{~m}$ & $\begin{array}{l}\text { Khondker et al. } \\
\text { (2008) }\end{array}$ \\
\hline
\end{tabular}

From the diatom population of the Haor, a total of 14 species was recorded. Among the total recorded species, three belonged to centric and 11 to pinnate diatoms. Out of these 14 species, only 8 
species could be quantified (Table 1). Melosira granulata was the most dominant diatom in the system. The recorded density of M. granulata from Watch Tower and Rauar Station were $291 \times 10^{3} \mathrm{ind} / 1$ and $34.5 \times 10^{3} \mathrm{ind} / \mathrm{l}$, respectively. Six taxa, namely Surirella ovata var. pinnata, M. granulata var. angustissima, Coscinodiscus lineatas, Cocconeis placentula, Cymbella turgidula and Eunotia veneris were recorded just as present in the pelagic water of the haor. The density of the euglenoid population was relatively lower in the haor water. A total of four species was recorded and cell densities of those varied from $1.5-4.5 \times 10^{3} \mathrm{ind} / 1$.
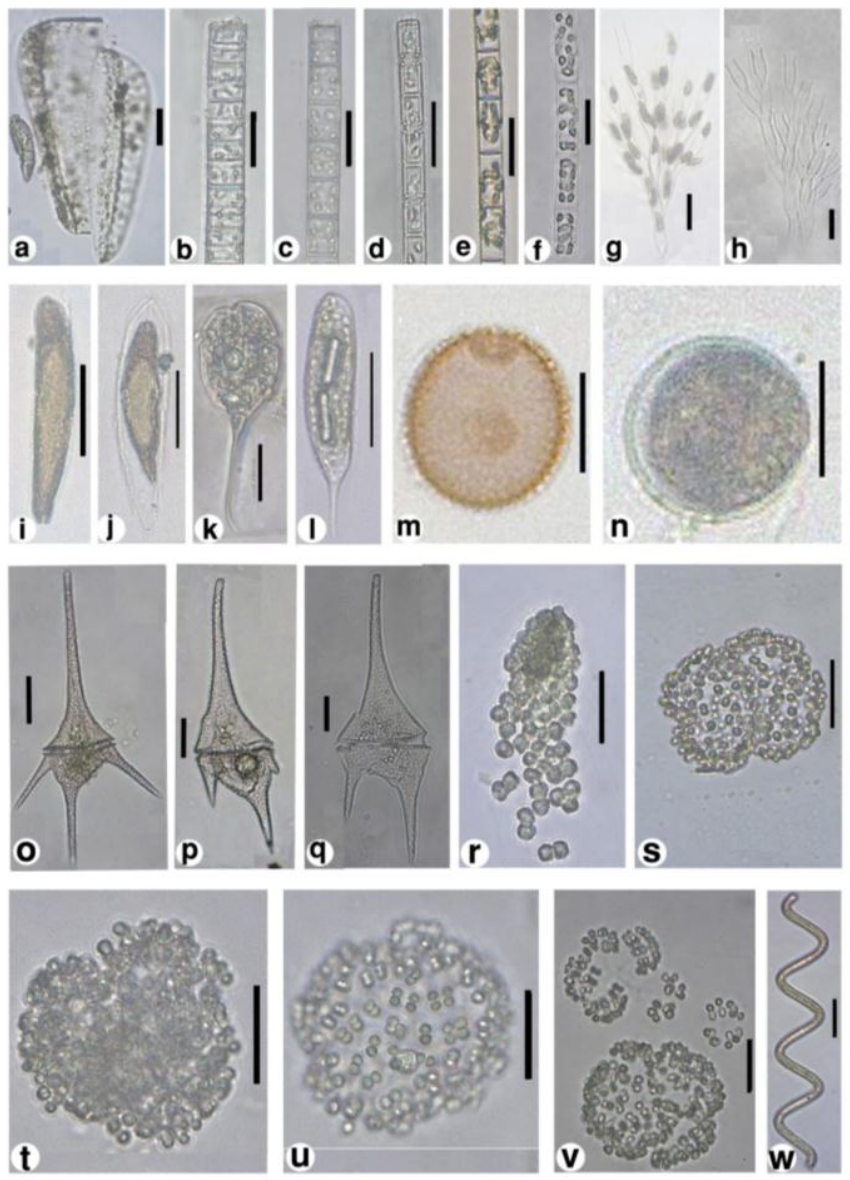

Figs. 1. Photomicrographs of phytoplankton from Tanguar Haor: a. Surirella ovata var. pinnata; b-c. Melosira granulate; d-f. M. granulata var. angustissima; gh. Dinobryon sertularia; i-j. Mallomonas akrokomos; k. Phacus longicauda; 1. Euglena charkowiensis; m. Trachelomonas racibowrski; $\mathbf{n}$. Trachelomonas volvocina; o-q. Ceratium furca; $\mathbf{r}$. Chroococcus disperses; $\mathbf{s - v . \quad M i c r o c y s t i s}$ marginata; and w. Arthrospira platensis. (In figs. a, b, c, d, e, f, g, h, i, j, k, l, o, p, q, u, v and w, Scales $=40 \mu \mathrm{m})$ and (In figs. $\mathrm{m}, \mathrm{n}$ and $\mathrm{r}$, Scales $=20 \mu \mathrm{m}$ ).
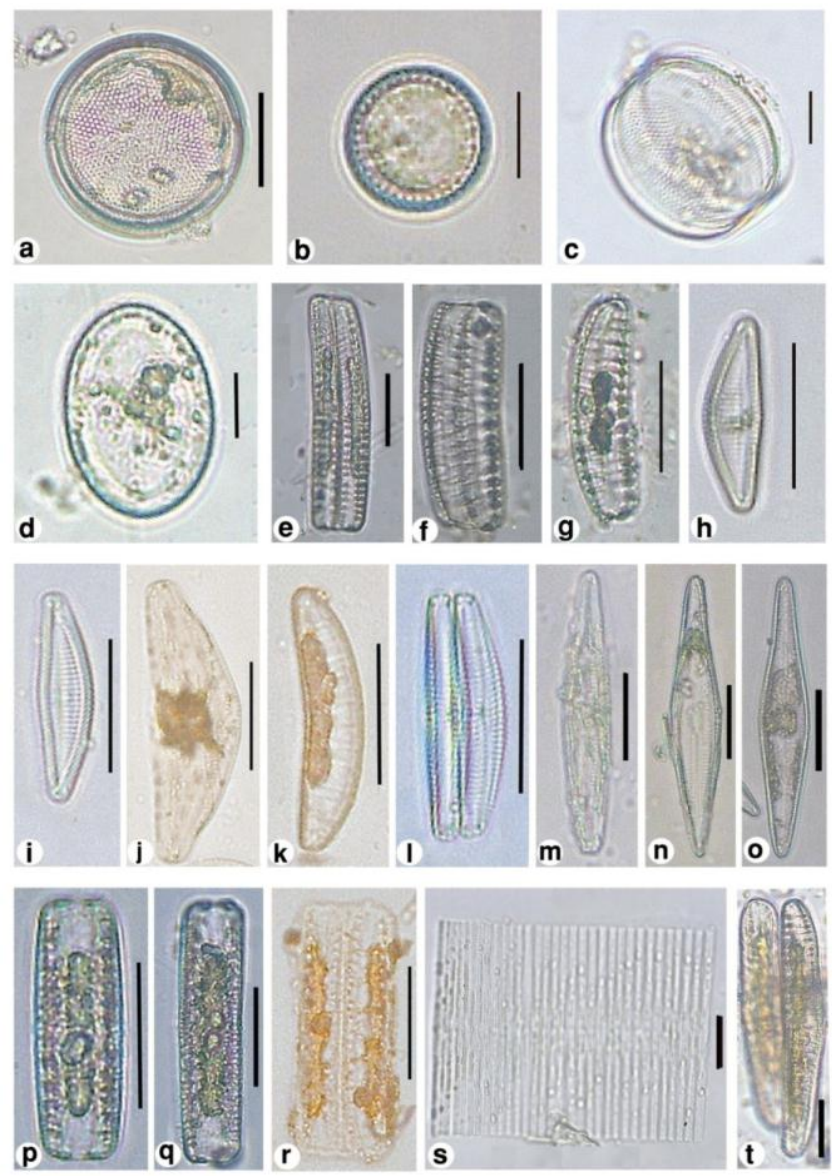

Figs. 2. Photomicrographs of phytoplankton from Tanguar Haor: a and c. Coscinodiscus lacustris; b. C. lineatas; d. Cocconeis placentula; e-g. Denticula tenuis; h-i. Cymbella cistula; j. Cymbella turgidula; k-l and t. Eunotia veneris; $\mathbf{m}$. Gomphonema lanceolatum; n-o. G. gracile; p-r. Eunotia monodon; and s. Fragilaria virescens. (In figs. a, e, f, g, h, i, j, k, l, m, n, o, p, q, r, d and t, Scales $=40 \mu \mathrm{m}$ ) and (In figs. b, c and d, Scales $=$ $20 \mu \mathrm{m})$

In the present study, at Watch Tower Station Dinobryon sertularia was found most dominant phytoplankton followed by Ceratium furca, Microcystis marginata and Melosira granulata (Table 1). Similar trend was also found at Rauar Station but the population of the individual species was relatively 
lower compared to the Watch Tower Station. However, the presence of Dinobryon abundantly in the pelagic water of Tanguar Haor shows that its productivity is moderate (Reynolds 1984).

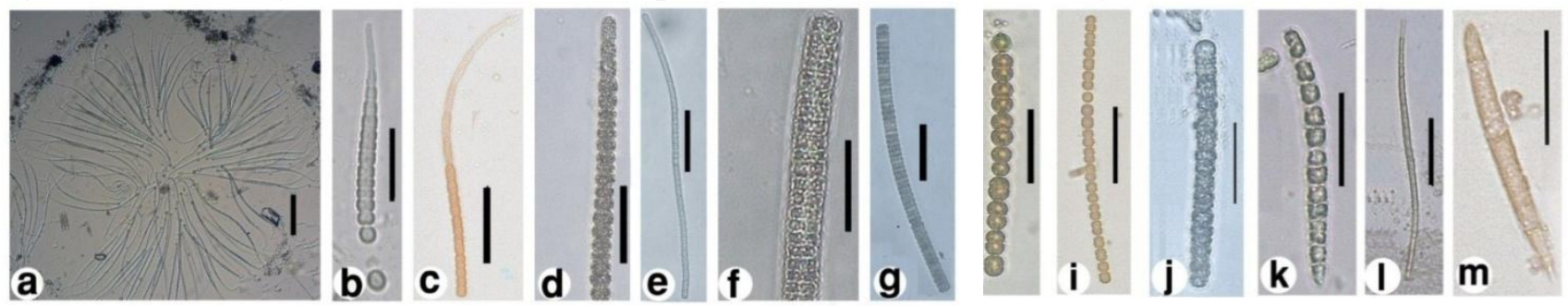

Figs. 3. Photomicrographs of phytoplankton from Tanguar Haor: a. Gloeotrichia echinulata; b. Rivularia globiceps; c. Raphidiopsis mediterranea; d. Oscillatoria Formosa; e. O. tenuis; f. O. peronata; g. O. chalybea; h. Pseudanabaena schmidlei; i. Anabaena constricta; j. Anabaena affinis; $\mathbf{k}$ and $\mathbf{m}$. A. californica; $\mathbf{l}$. Anabaenopsis racibowrski. (In figs. a, b, c, d, f, g, h, I, j, k, 1 and m, Scales $=40 \mu \mathrm{m}$ ) and (In fig. e, Scale $=20$ $\mu \mathrm{m})$.

In planktonic population, Dinobryon has been recorded from a hilly water body of Maulvi bazar and Kaptai Lake, though these studies do not reveal any size of the population (Islam and Khair 1978, Islam and Irfanullah 2005). Recently, Bhuiyan et al. (2019) based on the phytoplankton biomass as chlorophyll a, Sechhi depth and the concentration of soluble reactive phosphorus designated Tanguar Haor as mesotrophic which is also supported by the results of the present investigation.

Table 2. Taxonomic summary of the phytoplankton community of Tanguar Haor (both Watch Tower and Rauar stations) as represented by the algal divisions excluding Chlorophyta.

\begin{tabular}{|l|l|c|c|c|}
\hline \multicolumn{9}{|c|}{ Taxonomic entities of Algae examined } & Total \\
\hline \multirow{2}{*}{ Division } & Order & $\begin{array}{l}\text { Species number } \\
\text { (population quantifiable ) }\end{array}$ & $\begin{array}{l}\text { Species number (population } \\
\text { not quantifiable) }\end{array}$ & - \\
\hline \multirow{2}{*}{ CYANOPHYTA } & Chroococcales & 2 & 13 & 2 \\
\cline { 2 - 5 } & Nostocales & 2 & - & 15 \\
\hline PHYRRHOPHYTRA & Peridiniales & 2 & - & 2 \\
\hline \multirow{3}{*}{ CHRYSOPHYTA } & Ochromonadales & 2 & 2 & 4 \\
\cline { 2 - 5 } & Centrales & 2 & 4 & 10 \\
\cline { 2 - 5 } & Bacillariales & 6 & - & 4 \\
\hline EUGLENOPHYTA & Euglenales & 4 & Total species number & 39 \\
\hline
\end{tabular}

Floristic work in the Haor ecosystems of Bangladesh is poor. Islam and Paul (1978) investigated the Hakaluki Haor of Maulvi bazar district (formerly in the Sylhet district) from hydrobiological viewpoint. Among the phytoplankton flora they had examined, they could go up to the generic level mostly, with a few, up to species. Among those, 5 genera/species belonged to Euglenophyta, 6 to Chrysophyta and 4 to Cyanophyta (Islam and Paul 1978). The authors, however, did not report any taxa from the Division Phyrrhophyta. So, on a total at least 15 taxa were recorded from the Haor Hakaluki. A taxonomic summary of the phytoplanktonic flora from the Tanguar Haor has been presented in Table 2. From Table 2 it is seen that 39 species were recorded from 4 algal Divisions and 7 Orders in Tanguar Haor. The number of phytoplankton species recorded from 4 algal divisions (Cyanophyta, Phyrrhophyta, Chrysophyta and Euglenophyta) in Tanguar Haor is 2.6 times higher than Hakaluki Haor (Islam and Paul 1978). 


\section{ACKNOWLEDGEMENTS}

The research was supported by Special Allocation Project for the Year 2016-2017 under the Ministry of Science and Technology. Government Order (GO) No: 39.00.0000.09.02.069.16-17/11. Gr. SL.: 44 ES to the first author, which is duly acknowledged here.

\section{REFERENCES}

Ahmed, S. U., M. Khondker, Z. N. T. Begum, M. A. Hassan, S. M. H. Kabir, M. Ahmad, A. T. A. Ahmed and A. K. A. Rahman. 2008 (eds). Encyclopedia of Flora and Fauna of Bangladesh. Vol. Algae. Charophyta-Rhodophyta (Achnanthaceae to Vaucheriaceae), Asiatic Society of Bangladesh. Dhaka. 543 pp.

Bhuiyan, M. A. H and M. Khondker. 2018. Water quality and potamoplankton of the river Buriganga and Gomti: A comparison. Dhaka Univ. J. Biol. Sci. 27(2): 191-200.

Bhuiyan, M. A. H., S. A. M. S. Islam, A. Kowser, M. R. Islam, S. A. Kakoly, K. Asaduzzaman and M. Khondker. 2018. Phytoplankton in relation to water quality of Tanguar haor ecosystem, Bangladesh: 1. Rauar station. Dhaka Univ. J. Biol. Sci. (in press).

Bhuiyan, M. A. H., S. A. M. S. Islam, A. Kowser, M. R. Islam, S. A. Kakoly, K. Asaduzzaman and M. Khondker. 2019. Phytoplankton in relation to water quality of Tanguar haor ecosystem, Bangladesh: 2. Watch Tower station. Dhaka Univ. J. Biol. Sci. (in press).

Desikachary, T. V. 1959. Cyanophyta. Indian Council of Agric. Research, New Delhi. 686 pp.

Dillard, G. E. 2000. Freshwater algae of the South Eastern United States. Part 7. Pigmented Euglenophyceae. Bibliotheca Phycol. Vol. 106. J. Cramer, Berlin, Germany. 135 pp.

Germain, H. 1981. Flore des diatomees Diatomophycees. Societe Nouvelle des Editions Boubee, Paris. $444 \mathrm{pp}$.

Huber-Pestalozzi, G. 1968. Das Phytoplankton des Süsswassers. Systematik und Biologie. 3. Teil: Cryptophyceae, Chloromonadophyceae, Dinophyceae. E. Schweizerbart'sche Verlagsbuchhandlung (Nägele u. Obermiller), Stuttgart, Germany. 322 pp.

Hustedt, F. 1930. Die Suesswasserflora Mitteleuropas. Heft. 10, Bacillariophyta (Diatomeae). Verlag Gustav Fisher, Jena. 466 pp

Islam, A. K. M. N. and A. K. Y. Haroon. 1975. Limnological studies of the river Buriganga. II. Biological aspect. Dacca Univ. Stud. B. 21(1): 25-44.

Islam, A. K. M. N. and N. Paul. 1978. Hydrobiological study of the haor Hakaluki in Sylhet. J. Asiatic Soc. Bangladesh (Sci.). 4(1): 83-91.

Islam, A. K. M. N. and A. Khair. 1978. Report of some phytoplankton from lake Kaptai, Chittagong Hill-Tracts. Dacca Univ. Stud. B. 26(2): 53-61.

Islam, A. K. M. N., M. Khondker and S. Haque. 1991. Euglenoid algae of four polluted ponds in and around Dhaka city. Bangladesh J. Bot. 20(1): 7-15.

Islam, A. K. M. N. and H. M. Irfanullah. 2001. Some new records of algae for Bangladesh: Cyanarcus, Chloremys, Myrmecia, Selenodictyum, Tetraplektron and Pseudostaurastrum. Bangladesh J. Plant Taxon. 8(2): 1-7. 
Islam, A. K. M. N. and H. M. Irfanullah. 2005. Hydrobiological studies within the tea gardens at Srimangal, Bangladesh. II. Algal Flora (excluding Chlorophyceae). Bangladesh J. Plant Taxon. 12(1): $33-52$.

Islam, A. K. M. N. and J. Khundker. 2003. Algal flora of Brackishwater shrimp-culture ponds at Khulna, Bangladesh. I. Cyanophyceae. Bangladesh J. Plant taxon. 10(2): 57-71.

Islam, A. K. M. N. and K. M. Zaman. 1975. Limnological studies of the river Buriganga. III. Biological aspect. J. Asiatic Soc. Bangladesh (Sci.). 1: 45-65.

Khondker, M. 2009. Euglena charkowiensis Swirenko. In: Z. U. Ahmed, M. Khondker, Z. N. T. Begum, M. A. Hassan, S. M. H. Kabir, M. Ahmad, A.T.A. Ahmed and A.K.A. Rahman (eds.). 2008. Encyclopedia of Flora and Fauna of Bangladesh. Vol. 4. Algae, Charophyta-Rhodophyta (Achnanthaceae-Vaucheriaceae), Asiatic Society of Bangladesh, Dhaka. 237 pp.

Khondker, M., A. K. M. N. Islam, Z. N. T. Begum and S. Haque. 1990. Limnological studies of four polluted ponds in and around Dhaka city with reference to indicator species. Bangladesh J. Bot. 19(1): 51-63.

Khondker, M., R. A. Bhuiyan, J. Yeasmin, M. Alam, R. B. Sack, A. Huq and R. R. Colwell. 2006. New records of phytoplankton for Bangladesh. 1. Cyanophyceae. Bangladesh J. Bot. 35(2): 173-179.

Khondker, M., R. A. Bhuiyan, J. Yeasmin, M. Alam, R. B. Sack, A. Huq and R. R. Colwell. 2008. New records of phytoplankton for Bangladesh. 8. Trachelomonas Ehr. Bangladesh J. Bot. 37(2): 133139.

Ling, H. U. and P. A. Tyler. 2000. Australian Freshwater Algae (exclusive of diatoms). Bibl. Phycol. Bd. 105.J. Cramer, Berlin. 643 pp.

Prescott, G. W. 1982. Algae of the Western Great Lakes Area. Otto Koeltz Sci. Publ., W-Germany. 977 pp.

Reynolds, C. S. 1984. The ecology of freshwater phytoplankton. Cambridge Univ. Press, Cambridge. 384 pp.

Wetzel, R. G. and G. E. Likens. 2000. Limnological Analysis. W.B. Saunders Co. Philadelphia. 357 pp. 
